\title{
Communicating with illiterate consumers
}

\author{
P.J. du Plessis and Truida Prekel \\ School of Business Leadership, University of South Africa, Pretoria
}

\begin{abstract}
Communicating effectively with consumers is a major problem facing marketers world-wide. In South Africa a substantial proportion of adult consumers are illiterate. Considerable potential could be unlocked if marketers were to differentiate or expand their communication strategy to specifically address illiterate consumers. It is estimated that between $\mathbf{4 0} \%$ and $50 \%$ of adult blacks in South Africa are illiterate. Exploratory research was undertaken to establish how a sample of illiterate and semi-literate blacks perceived, recognized and understood a selection of printed advertisements of consumer products. Results indicate that respondents have a high recognition of product application, and a fairly high recognition of brand names. In some cases message distortion and misinterpretation occurred, indicating that advertisers must ensure that communication with this market segment is clear, possibly by portraying a functional or product application setting. Certain brand names have become 'elevated' to generic names, and respondents tend to have fairly strong brand preferences for certain grocery products. Female respondents appear to be an important target group for advertisers of domestic consumables and grocery items because many of them influence product choice both in their own, and in their employers' homes. Marketers should establish to what extent illiterates constitute an important market segment for them, and devise specific ways to communicate with this large group of 'unnoticed' consumers.

S. Afr. J. Bus. Mgmt. 1986, 17: 175-181
\end{abstract}

Effektiewe kommunikasie met verbruikers is ' $n$ belangrike probleem wat bemarkers wereldwyd ondervind. In Suid-Afrika is ' $n$ aansienlike gedeelte van volwasse verbruikers ongeletterd. 'n Aanmerklike potensiaal kan ontsluit word indien bemarkers hulle kommunikasiestrategie sou differensieer en uitbrei sodat dit ook op ongeletterde verbruikers gerig word. 'n Geskatte $40 \%$ tot $50 \%$ van volwasse swart mense in Suid-Afrika is ongeletterd. Verkennende navorsing is onderneem om vas te stel hoe ' $n$ steekproef van ongeletterde en semi-geletterde swart volwassenes 'n verskeidenheid advertensies van verbruikersprodukte wat in gedrukte media verskyn, sou waarneem, herken en verstaan. Resultate dui daarop dat respondente 'n hos herkenning van produkaanwending getoon het en 'n redelik hoë herkenning van handelsname. In sommige gevalte het daar boodskapverwringing en waninterpretasie plaasgevind. Dit toon aan dat adverteerders moet verseker dat kommunikasie met hierdie marksegment duidelik is; waar moontlik, moet die produk in 'n funksionele of produkaanwendingsituasie geadverteer word. Sekere handelsmerke is tot generiese name 'verhef' en respondente het geneig om redelike sterk handelsmerkvoorkeure vir sekere kruideniersware te toon. Vroulike respondente kan 'n belangrike teikengroep vir adverteerders van huishoudelike verbruiksitems asook ander kruideniersprodukte wees. Baie van hulle beinvloed produkkeuse in hulle eie sowel as hul werkgewer se huishoudings. Bemarkers behoort vas te stel in watter mate ongeletterde verbruikers 'n belangrike marksegment vir hulle verteenwoordig; en bemarkers hoort bepaalde tegnieke te ontwikkel om met hierdie groot 'ongemerkte' groep verbruikers te kommunikeer.

S.Afr. Tydskr. Bedryfsl. 1986, 17: 175- 181

\section{P.J. du Plessis" and Truida Prekel}

School of Business Leadership, University of South Africa, P.O. Box 392, Pretoria, 0001 Republic of South Africa

*To whom correspondence should be addressed

\section{I don't think that most businesspeople understand the magnitude of our high illiteracy rate. For example, illiterates and functional illiterates can't read advertise- ments, direct-mail pieces, the Yellow Pages, loan contracts, instructions on medicine bottles, or directions on food packages.' - Johathan Kozol, Director, National Literacy Coalition, USA.}

Communicating effectively with consumers is probably the major problem facing marketing managers and advertisers world-wide. If a major target market consists of illiterate consumers with a wide range of language and cultural backgrounds - as is the case in South Africa - the problem is compounded.

From the limited literature available on the interface between illiteracy and marketing, it appears that to date most research on illiteracy has been done by sociologists and educationists. Discussions the authors have had with marketers also indicate that few South African marketers consciously cater for illiterate consumers in their advertising strategy even though these people represent a large segment of the market for many products.

Because so little information is available on this aspect of marketing, the authors did an exploratory study on product awareness and brand recognition of packaged goods among a sample of illiterate blacks in Pretoria, in order to establish the subjects' response to printed advertisements of certain consumer goods in the basic commodity range. The objective of the study was to get a feel for the problem, and establish pointers for future research.

Illiterate consumers - in many cases low-income black people - spend a large proportion of their income on basic commodities. These commodities are distributed mainly through retail outlets such as supermarkets. Advertisers of basic commodities use mainly print and audio or audio-visual media to reach their target audiences. In the case of packaged goods, limited person-to-person marketing contact is required, particularly in the case of sale through super- or hypermarkets. The 'pull strategy' by means of advertising to the end-user appears to be the preferred promotion tool. In 1984, marketers spent a total of R165 million on advertising basic commodities (MRA, 1984).

According to a sociological study of urban black people, they see advertising in a positive light, and black consumers have greater confidence in products that are widely advertised (The Bates Group, 1982). As such, advertising has a strong influence on the South African black market. When trying to bring a product to the attention of illiterate consumers, however, it is unclear to what degree traditional advertising 
succeds in getting the message through.

A brief overview of relevant literature will be given, before the survey and its results are discussed. The paper will be concluded with some comments and suggestions.

\section{Literature on illiteracy and marketing}

Various definitions of literacy or illiteracy exist. Some are based on functional aspects, for example according to the UNESCO Expert Committee on Standardization of Educational Statistics: (Wedepohl, 1984:5).

'1. A person is considered literate, who can both read with understanding and write a short simple statement on his everyday life.

2. A person is considered semi-literate, who can read with understanding, but not write, a short simple statement on his everyday life'.

Other authors use years of schooling as a criterion, but here standards also vary:

'The number of years at school that is used as a criterion for literacy varies considerably in definitions: UNESCO's criterion for literacy is four years: the Census Bureau and the United States Defence Force require five years, while the Education Department of the United States requires four to eight years' (Ellis, 1982:13).

For the purposes of this paper, we shall accept the following definition: An adult literate is a person of 15 years and older who either can read and write in at least one language, or has successfully completed five consecutive years at school (Ellis, 1982:13).

The problem of illiteracy is, of course, not unique to South Africa. Statistics vary according to researchers' perspectives and definitions used. The Statistical Abstract of the United States 1984 (US Department of Commerce, 1984:863 - 864) lists comparative statistics for various countries, showing illiterates in 1980 as a percentage of the total population, 15 years old and over. According to this list, some of the highest illiteracy rates occur in Upper Volta $(95,4 \%)$, Ethiopia $(95,2 \%)$, Mali $(89,9 \%)$, and Afghanistan $(88,7 \%)$. The lowest illiteracy rates are quoted for France, Germany, the Netherlands, Japan, Canada and Australia, all at $0,5 \%$.

Although this source also quotes a $0,5 \%$ rate for the United States of America, other sources indicate considerably higher illiteracy rates for the USA. According to Kozol (in Whalen, 1983:1), about 60 million American adults - or one third of the adult population - are illiterate. Of these, 25 million are totally illiterate, and another 35 million are functionally illiterate. Kastor (1984:85) defined functional illiteracy in a practical way: 'They cannot read well enough to decipher the directions on a bottle of pills, to fill out a job application, to know if they are entering a grocery store or a hardware shop'. She estimated that more than 26 million American adults (or one in eight) are functionally illiterate.

In a discussion of the marketing research implications of illiteracy, Whalen (1983:18) quoted Kozol and warned marketers against assuming that illiterates constitute an economically insignificant consumer audience. 'While unemployment is extremely high among illiterates, they have massive purchasing power by virtue of their numbers alone'.

In the United States Statistical Abstract quoted above (US Department of Commerce, 1984:836 - 864) the illiteracy rate for South Africa is given as $20,7 \%$. This agrees broadly with other statistics. According to French (1982:75) there were over 6 million illiterates of all races in South Africa and the independent and self-governing states in 1980 . Total population in 1980 was 23772000 in South Africa and 4794000 in the independent neighbouring states (Republic of South Africa 1982). On this basis, the illiteracy rate was $21 \%$. But such an 'average' conceals more than it reveals because of the differences within the country's complex population. Broken down by race group, and based on the 1980 census, Wedepohl (1984:10) provided the statistics in Table 1.

Table 1 Number of illiterate persons aged 15 years and over - selfassessed. South Africa, 1980

\begin{tabular}{lrr}
\hline Classified & Number & \multicolumn{1}{c}{$\%$} \\
\hline White & 23560 & 0,72 \\
Coloured & 246680 & 15,51 \\
Asian & 39180 & 7,59 \\
Total blacks & 3343140 & 33,05 \\
Total & 3652560 & \\
\hline
\end{tabular}

Source: Wedepohl (1984:10)

The fact that these statistics are based on self-assessment probably causes the illiteracy rate to appear lower than it actually is; this also explains the discrepancy between the total of 3,65 million, and the total of 6 million illiterates mentioned in the previous paragraph.

The Science Committee of the President's Council (1984) reported slightly higher percentages:

$\begin{array}{lr}\text { White } & 3,1 \% \\ \text { Coloured } & 18,1 \% \\ \text { Asian } & 9,6 \% \\ \text { Black } & 36,4 \% \text {. }\end{array}$

According to a 1982 newsletter of the Human Sciences Research Council (Literacy, 1982), it was estimated that between $50 \%$ and $60 \%$ of adult blacks in South Africa were literate. Thus, between $40 \%$ and $50 \%$ of adult blacks were illiterate. Even this may be an understatement in terms of practical, functional literacy, and the above illiteracy rates would probably be higher if other standards or definitions were used for literacy/illiteracy (Whalen, 1983:18). Further, Retief $(1983: 11-13)$ found that limited literacy skills are lost if they are not regularly used.

These high illiteracy rates among blacks pose a major problem for marketers who wish to communicate with black adults as a target audience. This problem is further compounded by several factors:

- People with literacy problems are often not exposed to the media in which printed advertisements are placed, or may misinterpret messages in printed advertisements.

- South African blacks speak many different languages. There are four main language groups (Nguni, Sotho, Tsonga and Venda); 23 sub-groups, and numerous dialects. To make matters worse, many of these vernaculars are undergoing rapid change, and usage tends to differ according to region, educational level and background (Prekel, 1983). This factor further restricts understanding of advertisements, causes major problems with translations and necessitates high production and placement costs for limited segments.

- Many urbanized blacks prefer speaking English, and in some cases Afrikaans, to their home language. Yet most of them are still more at home in the vernacular, particularly when dealing with abstract concepts (Retief, 1983).

- According to research by Els (1983:4-8) done in Soweto, understanding, acceptability and preference of 
advertisements vary according to language. Zulu is best understood, accepted and preferred, with English second and Tswana third in each case. North Sotho and Xhosa received fairly low ratings in Soweto. This will of course differ geographically.

- There are socio-cultural differences between urban and rural blacks, and between the cultures of the different groups and social strata (Motsepe, 1977:44). These differences must also be considered in the planning of advertisements.

\section{The survey}

Against this background, the authors undertook exploratory research in 1985 to establish how a sample of illiterate or semiliterate blacks perceived, recognized and understood a selection of printed advertisements that had appeared (in English) in newspapers or magazines directed at the black market, or in 'knock-and-drop' brochures.

A random sample of 56 respondents was drawn from a group of approximately $\mathbf{3 0 0}$ blacks attending literacy classes taught by volunteers at a church in an upper-middleclass suburb of Pretoria. A demographic breakdown of respondents will follow later.

A file of 12 full-colour advertisements was built up, showing a variety of eight packaged consumer products which could make up part of a black's shopping basket, as well as the logos of the four major supermarket chains.

Both authors conducted structured interviews with respondents, showing one advertisement at a time. The interviews were conducted in either English or Afrikaans, according to respondent preference. The interviewers took special care and time to ensure that respondents were at ease and understood questions.

\section{Demographics}

A brief demographic profile of respondents follows, as this may assist the reader in interpreting the results. Because this is only an exploratory study, the authors do not imply that this sample is representative of black illiterates. Owing to situational factors - the location of the 'school', and the fact that classes are given in the evening - the classes are not easily accessible to people living in black townships.

The respondents were mostly migrant domestic workers, coming from places like Groblersdal, Bethal, Pietersburg, Tzaneen, Rustenburg and Transkei. Most of them lived on the premises of their employers. Twenty-two of the 56 respondents $(39 \%)$ were men, and $34(61 \%)$ women.

Students at the literacy school attend night classes four times a week, and are divided into classes according to literacy level. Table 2 indicates the formal educational level completed by respondents. (At the school students who wish can write examinations of the Department of Education and Training.)

According to the previously stated criterion that a person must have completed five years of schooling to be regarded as literate, 46 of the respondents $(82 \%)$ were illiterate. The others were probably attending the school to upgrade or renew their skills.

There was a wide spread of language groups among the delegates. Northern Sotho and Tswana were predominant, each having a $23 \%$ share among respondents. Sixteen per cent of respondents were Zulu, $13 \%$ Ndebele-speaking, and $11 \%$ Pedi. The remaining $14 \%$ of respondents spoke Xhosa, Shangaan, Swazi or Tsonga at home. The age distribution is shown in Table 3.

The majority of the women - 32 women $(94 \%)$ - were in full-time domestic employment, with the other two women
Table 2 Educational level of respondents

\begin{tabular}{|c|c|c|c|c|c|c|}
\hline & \multicolumn{2}{|c|}{ Male } & \multicolumn{2}{|c|}{ Female } & \multicolumn{2}{|c|}{ Total } \\
\hline & Number & $\%$ & Number & $\%$ & Number & $\%$ \\
\hline No schooling & 14 & 64 & 19 & 56 & 33 & 59 \\
\hline Grade $1-2$ & 1 & 5 & 5 & 15 & 6 & 11 \\
\hline Standard $1-2$ & 3 & 13 & 4 & 12 & 7 & 13 \\
\hline Standard 3 & $\mathbf{0}$ & $\mathbf{0}$ & 0 & 0 & 0 & 0 \\
\hline Standard 4 & 1 & 5 & 2 & 6 & 3 & 5 \\
\hline Standard 5-6 & 2 & 9 & 3 & 9 & 5 & 9 \\
\hline Standard $7-8$ & 1 & 5 & 1 & 3 & 2 & 3 \\
\hline Standard $9-10$ & $\mathbf{0}$ & 0 & 0 & 0 & 0 & 0 \\
\hline Total & 22 & $101^{*}$ & 34 & $101^{*}$ & 56 & 100 \\
\hline
\end{tabular}

Allow for rounding errors

Table 3 Age distribution of respondents

\begin{tabular}{|c|c|c|c|c|c|c|}
\hline \multirow[b]{2}{*}{ Age } & \multicolumn{2}{|c|}{ Male } & \multicolumn{2}{|c|}{ Female } & \multicolumn{2}{|c|}{ Total } \\
\hline & Number & $\%$ & Number & $\%$ & Number & $\%$ \\
\hline $18-24$ & 3 & 14 & 2 & 6 & 5 & 9 \\
\hline $25-34$ & 12 & 55 & 17 & 50 & 29 & $S 2$ \\
\hline $35-44$ & 5 & 23 & 14 & 41 & 19 & 34 \\
\hline $45-54$ & 2 & 9 & 1 & 3 & 3 & 5 \\
\hline \multirow[t]{2}{*}{$55+$} & - & - & - & - & - & - \\
\hline & 22 & $101^{a}$ & 34 & 100 & 56 & 100 \\
\hline
\end{tabular}

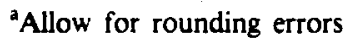

$(6 \%)$ in part-time domestic employment. The men represented a wider variety of occupations: Seven $(32 \%)$, were fulltime domestic workers or gardeners, four $(18 \%)$ were parttime gardeners, and the balance $(50 \%)$ were in industry or commerce.

The cash income distribution was wide, as can be seen in Table 4.

The cash remuneration of the female respondents is clearly less than that of the males. This could partly be ascribed to traditional pay discrimination found world-wide (Human, 1982:33 - 34); partly to differences in occupations. The fact that most domestic workers also receive remuneration in kind (accommodation, food, clothing and goods) could mean that their total remuneration is considerably higher.

\section{Survey results}

The first exhibit shown to respondents was a full-colour advertisement of Rama margarine (Figure 1). Respondents were asked whether and where they had seen the advertisement. A

Table 4 Income distribution of respondents (rand per month)

\begin{tabular}{|c|c|c|c|c|c|c|}
\hline \multirow[b]{2}{*}{ Rand } & \multicolumn{2}{|c|}{ Male } & \multicolumn{2}{|c|}{ Female } & \multicolumn{2}{|c|}{ Total } \\
\hline & Number & $\%$ & Number & $\%$ & Number & $\%$ \\
\hline $51-100$ & 2 & 9 & 7 & 21 & 9 & 16 \\
\hline $101-150$ & 1 & 5 & 23 & 68 & 24 & 43 \\
\hline $151-200$ & 6 & 27 & 3 & 9 & 9 & 16 \\
\hline $201-300$ & 7 & 32 & 1 & 3 & 8 & 14 \\
\hline $301-400$ & 4 & 18 & 0 & 0 & 4 & 7 \\
\hline $401-500$ & 0 & 0 & 0 & 0 & 0 & 0 \\
\hline \multirow[t]{2}{*}{$501+$} & 2 & 9 & 0 & $\mathbf{0}$ & 2 & 4 \\
\hline & 22 & 100 & 34 & $101^{*}$ & 56 & 100 \\
\hline
\end{tabular}

Allow for rounding errors 


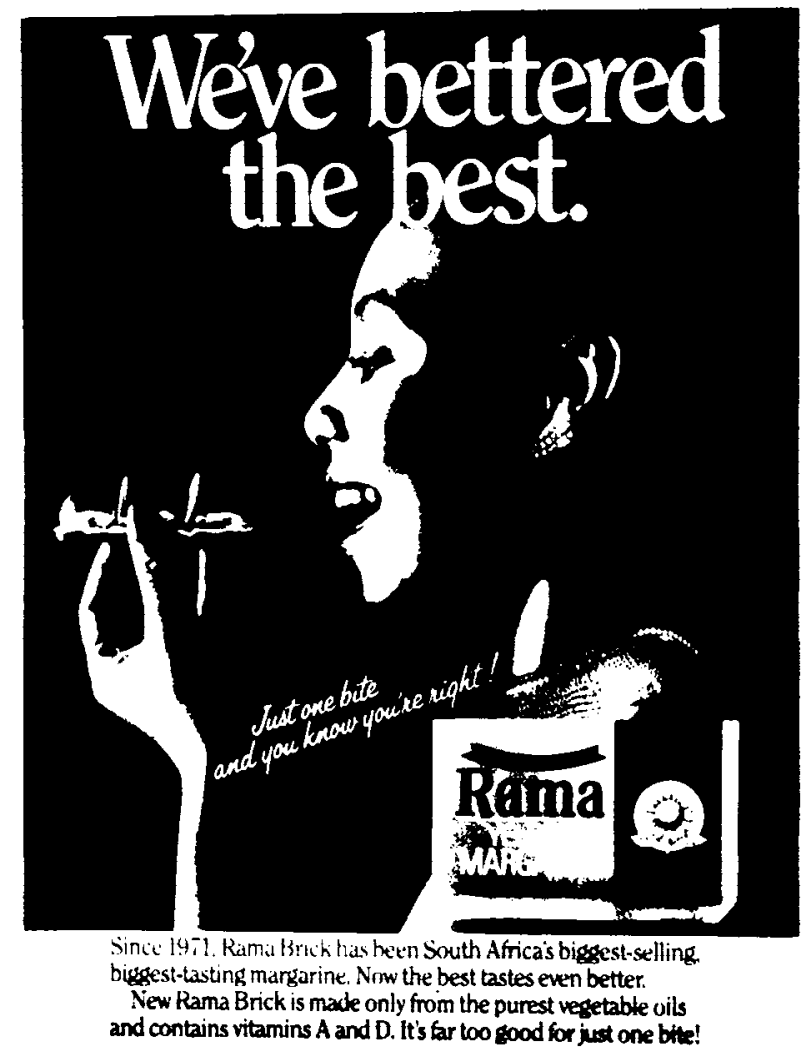

Figure 1 Full-colour advertisement shown to respondents.

Table 5 Ascribed source of exposure to Rama advertisement

\begin{tabular}{lccr}
\hline Media source & $\begin{array}{c}\text { Number of } \\
\text { respondents }\end{array}$ & $\begin{array}{c}\text { Multiple } \\
\text { exposure }\end{array}$ & Total \\
\hline Television & 18 & 3 & 21 \\
Magazines & & & 9 \\
- Bona & 2 & & \\
- Huisgenoot & 1 & & \\
- "Zulu" & 1 & & \\
- Unspecified & 5 & & \\
Newspapers & 2 & & \\
In-store displays & & \\
- Checkers & 2 & \\
- Hyperama & 1 & \\
- OK & 1 & \\
- Pick-'n-Pay & 1 & \\
- Unspecified & 2 & \\
Bus shelters & 3 & \\
\hline
\end{tabular}

total of 39 respondents $(70 \%)$ had seen it; $71 \%$ of the women and $68 \%$ of the men said they had seen it, from which it appears that in this case there was not much difference in exposure and recognition between the sexes.

The question regarding the source of exposure elicited a wide range of responses which are given in Table 5. Some respondents stated that they had seen the advertisement in more than one place.

The responses are reported as given, without implying that the respondents' perception or recall of the source was correct - for example, there is no magazine called 'Zulu', and this advertisement aimed at black consumers did not appear in 'Die Huisgenoot'.

From discussions with the advertiser of Rama it appears that this particular advertisement appeared in magazines as part of a larger campaign run mainly on television. Besides magazines, other non-electronic media such as in-store displays, bus shelter adverts and billboards were also used for reinforcement by means of image transfer.

It must be borne in mind that most of the respondents are domestics living in 'white' suburbs. Thus they are less exposed to outdoor media like billboards and bus shelter advertising than commuting township dwellers would be.

A content analysis was done to reduce the diverse responses regarding recognition and understanding of the Rama advertisement. Firstly, 25 respondents, or $44 \%$, identified the brand name correctly, and 16 respondents $(29 \%)$ associated the advertisement positively with product benefits. Seven respondents $(13 \%)$ only recognized the product generically as margarine, and another seven said it was butter.

Examples of the positive messages mentioned are: 'Rama margarine - you must eat it every day'; 'Rama - for baking cakes, biscuits, spreading on bread - we must eat it'. 'If you want to be strong and healthy, you must eat Rama'.

Some of the statements relate to product applications, others to product benefits which are not directly stated or shown in the advertisement. Thus they could indicate beliefs regarding the brand.

The message of the advertisement was misunderstood by 11 respondents, most of whom only referred to food in general, two associating it with totally different products (Pro Vita and Milo). One respondent referred only to the model ('Mosotho woman'), and one did not know what the advertisement represented.

The responses above add up to more than the 56 because, for this qualitative survey, responses were double-counted in the content analysis - if, for example, one respondent recognized the brand name, and associated it with product attributes, or identified it generically as margarine.

Responses to the question: 'What do you like in this advertisement?' were also analysed by content. When respondents mentioned more than one attribute, their responses were noted in both categories. The most frequent product-related 'like' response (11) referred to Rama's taste; and seven responses referred to health or nutritional benefits. Another eight respondents mentioned a more general message, for example 'Eat Rama and bread', or 'Shows what to eat'.

However, what the respondents seemed to like best about the advertisement is not directly related to the product concerned. The model, her beauty, her jewellery, her clothes, were mentioned by 14 respondents whereas another eight respondents said they liked the woman and the food, without referring in any way to the Rama message. Two respondents merely said they liked the picture, whilst another six made general comments, for example 'Have a party', 'Bread and cucumber' or 'Nice sandwich'.

The fact that the model attracted the most positive reaction in the advertisement need not be negative for the product. If readers like the model, this attracts their attention, and if they identify with the model, it may reflect positively on the product image. But then it is necessary that they also notice the product and recognize the brand name.

The second set of exhibits consisted of full-colour illustrations of actual packaged products that had been cut out from seven advertisements, and pasted on a neutral background. Respondents were asked whether they knew the brand name 
Table 6 Brand and product recognition by respondents

\begin{tabular}{|c|c|c|c|c|c|c|c|}
\hline \multirow[b]{2}{*}{ Brand name } & \multirow[b]{2}{*}{ 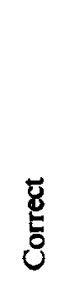 } & \multirow[b]{2}{*}{ 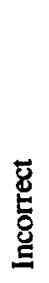 } & \multirow[b]{2}{*}{ 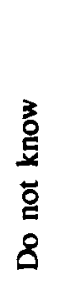 } & \multirow[b]{2}{*}{$\begin{array}{l}\text { Generic } \\
\text { product } \\
\text { description }\end{array}$} & \multicolumn{3}{|c|}{$\begin{array}{l}\text { Product } \\
\text { application }\end{array}$} \\
\hline & & & & & 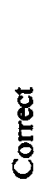 & 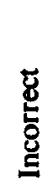 & 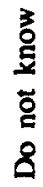 \\
\hline 1. Dettol & 34 & - & 22 & Disinfectant & 53 & 2 & 1 \\
\hline 2. Rondo & 27 & 9 & 20 & Margarine & 47 & - & 9 \\
\hline \multicolumn{8}{|l|}{ 3. I\&J Yankee } \\
\hline Clippers & 11 & 2 & 43 & Frozen Fish & 38 & 7 & 11 \\
\hline 4. Johnson's & 11 & - & 45 & Antiseptic powder & 7 & 44 & $s$ \\
\hline 5. Aquafresh & 28 & 9 & 19 & Toothpaste & 52 & 1 & 3 \\
\hline 6. Power Punch & 45 & 3 & 8 & Washing powder & 53 & - & 3 \\
\hline 7. Old Buck & 22 & - & 34 & Dry Gin & 17 & 36 & 3 \\
\hline
\end{tabular}

of the product and/or its application or use, in order to establish visual recognition of the sample of products. The results are summarized in Table 6.

\section{Product 1: Dettol}

The brand name was known to 34 respondents - the second highest 'score' of all seven products in this group, and also higher than the brand recognition of Rama discussed above under 'The first exhibit'. Fifty-three respondents gave a wide range of product applications, all relating to cleansing, toilet and/or disinfectant uses, and only three respondents did not know, or were incorrect about, product usage.

\section{Product 2: Rondo}

Less than half of the respondents (27) identified the brand name correctly, but 47 were correct about product application. Eight of the nine who indicated an incorrect brand name, gave the name 'Rama'; the other respondent said the brand name was butter. Concerning product application, responses of 'Rama' (5), 'butter' (10), 'margarine', and 'to spread on bread' were all accepted as correct. The fact that several respondents described Rondo as 'a kind of Rama' indicates that Rama has virtually become a generic name for margarine among some black consumers.

\section{Product 3: I \& J Yankee clippers}

Only 11 respondents could identify the product by brand name, even though 'I \& J', and variations such as 'Yankee Clips' were accepted as correct. With this product, which many respondents did not know, several tried to identify the product and its use by reading the words on the illustration. A possible explanation for the low brand recognition is the long, 'difficult' product name, and the fact that fish, particularly frozen fish, is relatively new in the black food basket. However, 38 respondents identified product application correctly, and the seven who indicated incorrect product use, mostly said it was chicken or meat. The researchers were tempted to regard one response, 'meat for chips', as correct, because the respondent may well have tried to indicate fish by association!

\section{Product 4: Johnson's antiseptic powder}

The brand name of this product was recognized by only 11 respondents - so that this product 'ties' with Product 3 above for lowest brand name recognition. This can probably again be ascribed to a long and 'difficult' brand name. As regards knowledge of product application, however, Product 4 differs markedly from Product 3 . Whereas 38 respondents knew what to do with Yankee Clippers, only seven knew the use of the antiseptic powder.

'Antiseptic powder', 'foot powder', 'under-arm' and 'shoe powder' were accepted as correct in terms of usage. Three respondents said it was similar to the baby powder, but for adults - these were also regarded as correct. The majority of respondents who stated an incorrect usage mistook the product for the well-known baby powder marketed by the same manufacturer in a similar package.

\section{Product 5: Aquafresh}

Although only half of the respondents (28) identified the brand name correctly, 52 were correct on product application. Of the 52 respondents who recognized the product in terms of use, 11 said it was 'Colgate', in several cases 'Colgate for teeth'. All nine respondents who identified the brand incorrectly, also said it was Colgate. It appears that we again may have a case where another brand of the same product group has gained 'generic status' in the eyes of black consumers - as in the Rondo/Rama case discussed under Product 2 above.

\section{Product 6: Power Punch}

This product attained the highest 'score' (45) for brand recognition, and tied with Product 1, Dettol, with 53 correct answers on product application. Of the three respondents who gave the incorrect brand name, two said 'OMO' and one 'Bingo'. Two respondents referred to Surf when asked about product application - possibly a more limited example of the Rama and Colgate 'generic syndrome'.

\section{Product 7: Old Buck dry gin}

Twenty-two respondents identified the product brand correctly, mostly as 'Old Buck', but some of them appear to have read the product name off the advertisement. In terms of application, 11 respondents identified the product as gin, and six as 'hard liquor', both accepted as correct. The 36 who were incorrect on product application, however, had a good idea that it was alcoholic: only one perceived it as a 'cooldrink', three said it was a 'drink', three said it was wine, six described it as either brandy, cane or whiskey, and 24 said it was beer. It appears as if beer has to some extent also become a generic name for alcoholic beverages, because beer is the traditional alcoholic drink among blacks. Although this was not specifically asked or recorded, many of the respondents said they did not drink alcoholic liquor themselves. One amusing response in this vein came from a woman who does not drink: 'It is probably hard liquor, because that Kudu could kill you with his sharp horns'.

It is interesting that only $32 \%$ of the women recognized the brand name, compared with $60 \%$ of the men. This difference could probably be explained by previous findings by Rocha-Silva (1985:VII) that black men drink more frequently and greater amounts of alcohol per year than do black women. Also found in the study by Rocha-Silva (1985:19) was that black women consume substantially less spirits than do black men, whilst the consumption of beer was higher than that of spirits for both groups.

\section{Brand choice of hot beverages}

Because instant coffee is a basic product in most shopping baskets, and blacks are major consumers of instant coffee 
(Brits \& Reekie: 169), respondents were asked what brand of instant coffee they used at their (family) homes. It emerged during early interviews that many respondents drank tea at home, rather than coffee. All responses, including brand choices of tea and other beverages, were thus recorded.

As far as instant coffees are concerned, Frisco (9) was the brand name most frequently mentioned, followed by Ricoffy (7) and Koffiehuis (4). FG was mentioned twice, and Nescafé and Van Riebeek once. Two respondents mentioned instant coffee ('kitskoffie') but no brand name. This brings the total of coffee drinkers to 26 , less than half of the total of $\mathbf{6 2}$ responses from 56 respondents, allowing for the six respondents who mentioned brand names for both tea and coffee.

Thirty respondents said they drank tea at home, with Joko (11) and Five Roses (8) the apparent leaders. Four drink Pitco, one Three Trees, and six 'Rooibos' tea. The balance of the 62 responses is made up by six respondents who said they drank Milo.

The case of 'Rooibos' tea is particularly interesting. All six respondents who expressed this preference were women, and none of them mentioned a brand name. While most other respondents merely gave the brand name of their coffee or tea of choice, the rooibos drinkers spontaneously expanded on why they preferred this herb tea. Several referred to health benefits. One (illiterate) woman volunteered that her grandmother had taught her to drink rooibos tea because it prevents phlegm on the chest; doesn't cause palpitations, and cures stomach ailments. 'It is both a tea and a medicine', she said. It is noteworthy that the scientifically proven anti-allergenic properties of this caffein-free beverage, were recognized among some uneducated blacks two generations ago.

Respondents were also asked how they had become aware of the particular brand of beverage that they usually drank. Parental (and in some cases grandparental) influence appears to be dominant: 27 respondents ( 20 women and seven men) said they had been influenced by their parents' usage of that brand. Employer usage influenced 14 respondents, and two had first tried the chosen brand at friends. Six respondents said they had been influenced by radio, and three by television advertisements.

\section{Influence on purchasing decisions}

Respondents were asked whether they ever suggested which specific brands of domestic consumables their employers should purchase. Of the 42 respondents in domestic employment (34 women and eight men), 30 said that they suggested particular brands by name to their employers, whereas $12 \mathrm{did}$ not. The question did not apply to the balance of respondents employed elsewhere.

For this question, five generic products which domestic workers would use in their daily work were identified, and respondents were asked which brand they would suggest to their employer. The responses are summarized in Table 7. Responses do not add up to 30 , because some respondents did not express preferences on all products.

It appears that those respondents in this study that suggest brand names to employers, have a strong brand loyalty to Tastic Rice, Sunlight Dishwasher and Handy Andy.

\section{Buyer role in own family}

Respondents were asked who bought groceries for their own family consumption. Thirty-three of the $\mathbf{3 4}$ women said they bought their families' groceries themselves, and six of them said that relatives (mother, sister, brother) also bought groceries, particularly when the respondents were away at work.
Table 7 Brand preferences on domestic consumables

\begin{tabular}{|c|c|c|c|c|c|c|}
\hline \multirow{2}{*}{$\begin{array}{l}\text { Generic } \\
\text { product } \\
\text { Rice }\end{array}$} & \multicolumn{2}{|c|}{$\begin{array}{c}\text { Brand } \\
\text { preferred } \\
\text { (respondents) }\end{array}$} & \multicolumn{2}{|c|}{$\begin{array}{l}\text { Runner up } \\
\text { (respondents) }\end{array}$} & \multicolumn{2}{|l|}{ Others } \\
\hline & Tastic & (25) & - & & - & \\
\hline Dishwasher & Sunlight & (25) & - & & $\begin{array}{l}\text { Lux Liquid } \\
\text { Ajax }\end{array}$ & \\
\hline Washing powder & Omo & (14) & Surf & (10) & $\begin{array}{l}\text { Skip } \\
\text { Punch } \\
\text { Rinso } \\
\text { Sunlight } \\
\text { Biotex }\end{array}$ & $\begin{array}{l}\text { (6) } \\
\text { (f) } \\
\text { (1) } \\
\text { (1) } \\
\text { (1) }\end{array}$ \\
\hline Bath cleaner & Handy Andy & (25) & Vim & (2) & $\begin{array}{l}\text { Omo } \\
\text { Harpic }\end{array}$ & $\begin{array}{l}\text { (1) } \\
\text { (1) }\end{array}$ \\
\hline Oven cleaner & Zeb & (10) & - & & $\begin{array}{l}\text { Handy Andy } \\
\text { Sunlight }\end{array}$ & $\begin{array}{l}\text { (l) } \\
\text { (l) }\end{array}$ \\
\hline
\end{tabular}

There was a wider spread in the case of the men: eight of the 22 said they did the shopping, nine said their wives did the buying, and five said relatives in the extended family bought their groceries.

The retail outlets where family groceries are bought also varied, with Checkers (27) and OK (18) mentioned most frequently, and Hyperama (5), Spar (4) and Pick 'n Pay (1) as 'also-rans'. Seven respondents said that they bought their groceries at small shops or supermarkets near home.

\section{Recognition of retail logo}

Respondents were shown the logos of four major grocery retail chains to test for recognition. Table 8 shows the result.

Fifty-three of the 56 respondents $(95 \%)$ identified the OK logo correctly. This is considerably higher than the recognition of the other logos; and is particularly interesting in view of the fact that, as reported above, considerably more respondents do their grocery shopping at Checkers (27) than at OK (18). A number of reasons may explain this:

- The OK logo is simple and strong.

- The OK name is short.

- The OK name and logo have been established for many decades.

- The Checkers emblem was changed recently.

\section{Conclusions}

From the literature it is clear that a substantial proportion of illiterate adult consumers is black. It appears that this important segment of the consumer market has not been addressed specifically enough in most South African marketing programmes. Considerable potential could be unlocked if marketers of basic commodities were to differentiate or expand their communication strategy to cater specifically for illiterate consumers.

It appears from the survey that the illiterate and semi-literate respondents have a high recognition of product application, and a fairly high recognition of brand names, from printed

Table 8 Correct recognition of retail logos

\begin{tabular}{lcccc}
\hline $\begin{array}{l}\text { Company/ } \\
\text { Trade name }\end{array}$ & Checkers & Spar & OK & Pick 'n Pay \\
\hline Male $(n=22)$ & 20 & 19 & 21 & 17 \\
Female $(n=34)$ & 24 & 24 & 32 & 22 \\
Total & 44 & 43 & 53 & 39 \\
\hline
\end{tabular}


advertisements of products. Although they may not purchase printed media such as magazines, chance exposure to printed media, 'knock-and-drop' advertisements, and advertisements on billboards, on bus shelters and at point-of-sale appear to reinforce product familiarity - with positive effects on product image and confidence. This familiarity may have been established by image transfer from the electronic media. On the other hand familiarity may also have been established through experience (e.g. use in their parents' or their employers' homes) or through word-of-mouth.

A few points emerged from the responses to the Rama advertisement. Although both the product and the brand name are well known, several respondents did not understand the message correctly. A number of respondents were distracted by the attractive model. It appears that in designing advertisements aimed at illiterate consumers, great care must be taken to ensure that the message comes across simply and clearly. In this advertisement the product was shown in a social setting, probably to appeal to consumers' aspiration needs. It may be more effective to show such a product in a functional or product application setting if the message is to come across unambiguously to illiterate consumers.

An interesting aspect in regard to brand preferences that emerged from the research is the tendency for certain brand names to be 'elevated' to generic names. This was particularly strong in the case of Rama and Colgate. This factor is probably more important in the case of over-the-counter sales (for example in pharmacies or traditional retailers) where customers ask for products by name, than in the case of selfservice outlets. In self-service situations consumers may still compare prices and decide to buy a brand other than the 'generic' brand.

Several respondents tried to read the brand names of products they did not recognize. This suggests that simple, short brand names, written in clear, bold lettering should have an advantage in recognition and retention of brand name. Labels showing clear pictures of the content along with the brand name should also help. Marketers should bear this in mind in planning packaging, as well as advertisements. The advantage of short, simple names when marketing to illiterates was highlighted by the fact that although the majority of respondents buy their groceries from Checkers, more of them recognized the OK logo, than that of Checkers. The use of three-dimensional models of products, like those of Black Cat Peanut Butter seen in black townships, also seems appropriate.

For supermarkets with a large black clientele, it may also make sense to take the probable lack of reading skills into consideration when planning layout. Merchandising in logical groups and use of pictures may make it easier to locate and identify products.

From the survey it appears that the respondents have fairly strong brand preferences in the case of certain grocery products. This would naturally influence their purchases for their own families. But their influence could also go further than many marketers realize. In many cases, because the domestic worker is the end-user of certain consumables, she or he may influence the white employer's purchasing behaviour, by expressing brand preference. Not surprisingly, female respondents appear to have a stronger influence on product choice both in their families and with their employers - so they appear to be an important target group for advertisers of domestic consumables and groceries.

For many marketers, the illiterate black consumer is an unknown quantity. Some marketers may even deny their importance, or say that they are a diminishing segment in view of current efforts to develop literacy among blacks. But considering the facts that about half of the adult blacks in South Africa are estimated to be illiterate, that it is very difficult for adults to become fully literate, and that the backlog among young blacks may be aggravated by current school boycotts - we can expect to have large numbers of illiterate customers in South Africa for decades to come.

Depending on their particular product, it may be a worthwhile investment for many marketers to establish to what extent this market segment is important to them, and to devise specific ways to communicate with this large group of 'unnoticed' consumers.

\section{References}

Brits, R.N. \& Reekie, W.D. 1985. Marketing in South Africa. Johannesburg: Macmillan. South Africa. $377 \mathrm{p}$.

Ellis, C.S. 1982. The promotion of literacy in South Africa: number and distribution of literate Black adults. Pretoria: Report TLK/Lit2 Human Sciences Research Council. 76p.

Els, J. 1983. Understanding, acceptability and preference for advertisements in selected languages among Blacks in Soweto. Pretoria: Report no. 109. Bureau of Market Research. University of South Africa. $91 \mathrm{p}$.

French, E. 1982. The promotion of literacy in South Africa. Pretoria: Human Sciences Research Council. 133p.

Human, L. 1982. Some brief comments on research into equal pay for work of equal value with specific reference to women. $S$. Afr. J. Labour Rel., vol. 6, 3 \& 4 .

Xastor, E. 1984. Education: Confronting the Illiteracy Stigma. Washington Post, January, 23.

Literacy, 1982. Newsletter no. 140. Pretoria: Human Sciences Research Council.

Market Research Africa, 1984. Adindex. Selected report and 5 year trend.

Motsepe, O. 1977. Behavioural aspects of motivating the Black industrial worker. In: Organizational Behaviour. Readings for Management. Nasser, M.E., Van Veijeren, C.F., Venter, J.J. \& Schmikl, E.D. Johannesburg: McGraw-Hill Book Company. 249p.

Prekel, T. 1983. Multi-cultural communication: A challenge to managers. Paper delivered at the International Convention of the American Business Communication Association (November 21) New York.

Report of the Science Committee of the President's Council on Informal and non-formal Education in South Africa. 18 June 1984.

Republic of South Africa, 1982. Report no. 02-80-02-Population Census 80: Social Characteristics - Sample. Pretoria: Government Printer.

Retief, T. 1983. Communication problems associated with training of Black workers in industry. Paper at Technikon Conference (July) Pretoria: CSIR.

Rocha-Silva, L. 1985. Drinking in the RSA: 1982. Pretoria: Report S-130. Human Sciences Research Council. 39p.

United States Department of Commerce, 1984. Statistical abstracts of the United States. 104th Edition.

The Bates Group of Companies, 1982. The future is now. Johannesburg. 34p.

Wedepohl, L. 1984. A survey of illiteracy in South Africa. University of Cape Town: Extra Mural Studies Division.

Whalen, B. 1983. Illiteracy: The marketing research implications. Marketing News, vol. 17, no. 10. 